\title{
CORRELATION BETWEEN SPECIFIC IgM LEVELS AND PERCENTAGE IgG-CLASS ANTIBODY AVIDITY TO Toxoplasma gondii
}

\author{
Marcel LEITE, Sonia SICILIANO, Lucia Silvieri A. ROCHA, Maria Teresa R. JUSTA, Katia Regina CÉSAR \& Celso F.H. GRANATO
}

\begin{abstract}
SUMMARY
Toxoplasmosis is an usually asymptomatic worldwide disseminated infection. In its congenital presentation it may lead to abortion or fetal malformations. Antenatal evaluation is considered of paramount importance to identify seronegative women and allow for prophylaxis. Recent improvements in sensitivity of IgM tests has made IgM detection an extremely protracted acute phase marker, and IgG avidity evaluation test became necessary. Observation has shown that a correlation can be established between IgM levels and avidity percentages, suggesting that frequently the avidity test may not be necessary. In this study we analyzed Toxoplasma gondii IgM levels of 202 samples and their IgG avidity percentages, in order to define specific levels whose IgM quantification could by itself define serodiagnosis and therefore make the avidity evaluation unnecessary. We showed that for IgM levels bellow 2.0 and above 6.0 serodiagnosis of toxoplasmosis could be established without need of IgG avidity test. IgM levels between these two parameters are associated with varying avidity indexes highlighting the importance of its evaluation as a means to confirm toxoplasmosis. Following this demonstration it was possible to avoid the avidity test for $75 \%$ of the cases, to reduce the turnaround time and to reduce costs.
\end{abstract}

KEYWORDS: Toxoplasmosis; Toxoplasma gondii; Avidity; Congenital Toxoplasmosis; Serological diagnosis; IgM.

\section{INTRODUCTION}

Toxoplasmosis is a worldwide infection with an estimated half a billion individuals carrying antibodies against $T$. gondii $^{15}$. Studies have indicated that seroprevalence in Brazil ranges from 50\% to $80 \% 5$.

Although the disease usually follows a benign course, $10-20 \%$ of cases present inespecific and self-limited manifestations which may go undetected and thus unrecorded in patients' nosologic history ${ }^{1,7,14}$.

In its congenital form, manifesting when pregnant women contract the primary infection or experience reactivation of the disease during pregnancy, the fetus becomes exposed to tachyzoites, the evolutive form responsible for congenital infection, via the placenta $a^{6,10}$. Disease in the fetus can be severe, culminating in aborting, stillbirth, severe neonatal disease or prematurity. Late manifestations can also develop depending on the virulence of the agent ${ }^{2}$, degree of fetus exposure to the toxoplasma and the timing of conceptus infection ${ }^{12}$.

In cases diagnosed in early pregnancy, treatment of the pregnant mother using spiramycin can reduce the risk of congenital toxoplasmosis by up to $60 \%$. In the São Paulo region, the frequency of congenital infection attains 1 in 1000 newborns, giving an estimated total of 230 to 300 infected neonates per year ${ }^{8}$.
Diagnosis of toxoplasmosis is essentially based on laboratorial data, considering that definition of cases based on clinical data alone is somewhat unreliable. In addition, laboratorial findings can indicate the probable timing of infection onset ${ }^{12}$.

Up until the early 1990s, the presence of IgM class antibodies against toxoplasmosis was interpreted as diagnosis of the acute form of the disease ${ }^{4}$. However, introduction of highly sensitive immunoenzymatic tests to detect IgM revealed that low levels are able to persist for many months, even years, after acute infection. Such IgM antibodies are called residuals and their presence does not indicate recent infection. Hence, interpretation of the test became more complex for both clinicians and obstetricians thereby limiting its usefulness since it could not be ascertained whether the patient had acute infection or not, or if the infection was pre- or post-conceptional.

Several studies aimed at determining infection onset. These studies sought to associate the presence of $\operatorname{IgA}$ or $\operatorname{IgE}$ antibodies or assess the avidity of the bond of the IgG antibodies with antigens of the toxoplasm $3,5,12,13,16$. However, most of these studies presented significant limitations.

The avidity of an antibody for its antigen depends on various forces of interaction and may be determined chemically. This characteristic 


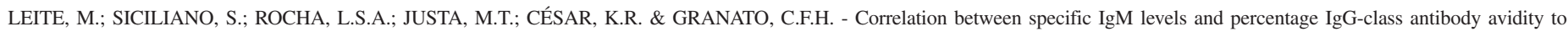
Toxoplasma gondii. Rev. Inst. Med. trop. S. Paulo, 50(4): 237-242, 2008.

depends on the chemical environment in which the reaction takes place, while the addition of certain substances can affect stable chemical reactions of the antibody with the antigen ${ }^{9}$. Immunoenzymatic tests allow straightforward and swift assessment of the degree of antibody avidity by elution or dilution using chaotropic substances such as guanidine, urea, diethylamine and ammonium thiocyanate.

A number of reports have shown that low levels of IgG avidity are good markers of recent infection, indicating disease onset some three to four months prior to blood collection, a period during which lowavidity antibodies have not yet been replaced by those of high-avidity ${ }^{10}$. Evaluation of toxoplasmosis IgG avidity levels of pregnant women and relating them to $\operatorname{IgM}$ reactivity has shown the latter to be better at predicting recent infection than isolated $\operatorname{IgM}$ detection since this immuneglobulin can persist longer in circulation leading to a false conclusion of recently acquired infection ${ }^{5,8,12}$.

The avidity test, originally developed for secondary use as an auxiliary test, became indiscriminately used as a key factor defining infection timing. As a consequence of this procedure, a high number of $\operatorname{IgM}$ reactive samples were evaluated to their levels of avidity resulting in very high or very low percentages which can be observed in the routine, leading the authors to believe that performing avidity tests is in many cases unnecessary ${ }^{8}$. This generates additional costs, delays a definitive serodiagnosis and causes anguish to pregnant women and obstetricians alike. Therefore, in order to rationalize the avidity test and its use for auxiliary purposes as originally intended, the $\operatorname{IgM}$ levels required to evaluate avidity and to diagnose infection must be established.

Moreover, although rare, patients have been described in which high avidity levels were never reached, further limiting application of the test in certain cases ${ }^{15}$.

Therefore, the objective of this study was to correlate levels of IgM directed to Toxoplasma, with IgG avidity percentages for the same parasite, with a view to establishing more accurate levels at which serodiagnosis can be determined using solely $\operatorname{IgM}$ values, and defining clearer concentration values for ordering the avidity test.

\section{MATERIALS AND METHODS}

Samples: Concentrations of $\operatorname{IgM}$ and $\operatorname{IgG}$ class antibodies to $T$. gondii, as well as $\operatorname{IgG}$ avidity, were obtained using analysis of sera from patients at Fleury Medicina e Saúde (FMS), who had undergone the tests outlined above between 01/08/2005 and 31/07/2006. No direct clinical information is available except the existence of pregnancy.

IgM anti-toxoplasma concentration: The Microparticle Enzymatic ImmunoAssay (MEIA) method was used, employing the Axsym $^{\circledR}$ automated analyzer (Abbott Laboratórios do Brasil LTDA). This method uses microparticles coated with $T$. gondii antigens which react to anti-toxoplasma antibodies present in the sample.

The results of concentrations produced by the analyzer were interpreted according to manufacturer's guidelines.

Determining anti-toxoplasma IgG avidity: Percentage IgG avidity tests were carried out in duplicate on serum samples by the immunoenzymatic method using microplates sensitized with $T$. gondii antigens.

After antibody-antigen complex formation, one of the duplicate slides was washed using a solution containing PBS-Tween and the other using a solution containing PBS-urea $6 \mathrm{M}$, the purpose of which was to eliminate non-bonded substances and to breakdown the bonds among low-avidity antibodies and antigens, respectively. Thus, in the case of urea, only complexes made up of high-avidity antibodies should remain.

Following the washing process, one duplicate contained antigenantibody complexes comprising low or high avidity anti-toxoplasma IgG antibodies, while the other contained only high-avidity antibodies, if these were present in the clinical sample. The next step in the immunoenzymatic reaction was the addition of the human-peroxidase anti-IgG specific conjugate with subsequent incubation for 60 minutes at $37^{\circ} \mathrm{C}$, in order to bond these to the antigen-antibody complexes present.

The two cavities of the duplicate slide were then rewashed using PBS-Tween. In the last phase, a solution was added containing tetramethylbenzidine chromogen substrate plus hydrogen peroxide, which after 20 minutes of incubation at room temperature and protected from light, reacts with the peroxidase present in the conjugate giving rise to the color. After the final incubation, sulfuric acid was added to stop the reaction and allow readings to be taken on the spectrophotometer.

Upon completion of this procedure the result of the analysis corresponds to the optical density obtained in each cavity of the microplate read by the spectrophotometer. Percentage avidity was calculated as the result of the optical density of the cavity washed with PBS-urea, divided by the optical density of the cavity washed with PBS-Tween, multiplied by 100 , as depicted in the formula below. $\frac{\text { O.D. of the microplate washed with PBS }+ \text { Urea }}{\text { O.D. of microplate washed with PBS }}$ X $100=\%$ high avidity antibodies

Results obtained for percentage IgG antibody avidity were interpreted as follows:

- $0-30 \%$ : Low avidity. Indicates that infection was acquired within approximately the last three months.

- $30-60 \%$ : Indeterminated period.

- 60 - 100\%: High avidity. Indicates that infection was acquired before three months ${ }^{11}$.

Obtaining other data on patients: Data regarding the laboratorial tests of patients from the FMS were stored on a computerized data base, accessible with the aid of the appropriate software. Results of IgM concentrations and percentage avidity studies were viewed using the Assessoria Médica Pró-Ativa (AMPA) and Results Checking software.

The AMPA software allowed the record numbers of patients who had visited the FMS between 01/08/2005 and 31/07/2006 for both tests above to be pooled. Patients who had undergone both concentration 


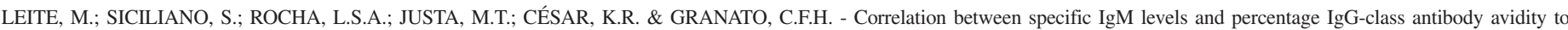
Toxoplasma gondii. Rev. Inst. Med. trop. S. Paulo, 50(4): 237-242, 2008.

tests over the study period were then identified. After identifying the pertinent patient record numbers using the AMPA software, the Results Checking software was employed. This second Software program enabled access, by record number, to information on laboratorial tests and characteristics of the patients involved. The following data were compiled from this information:

- Age and gender;

- Profile of pre-natal tests or of acute disease investigations;

- Result of IgM anti-toxoplasma concentration;

- Percentage avidity of IgG to T. gondii.

The medical tests requested for each patient were used to define the clinical investigation type of each case. Parameters used to define acute disease investigation-related cases included the presence of tests associated to an acute disease picture due to toxoplasma, cytomegalovirus or mononucleosis (EBV infection) among others. Parameters used to define pre-natal investigation-related cases, were the presence of tests associated to pre-natal screening including: syphilis, HIV, rubeola, toxoplasmosis and cytomegalovirus as well as direct information concerning pregnancy, when available.

\section{RESULTS}

As shown in Table 1, results for 202 cases were analyzed. More than fifty per cent of the subjects were in the 20 to 29 years or 30 to 39 years age brackets, where the latter age group accounted for the highest number of cases. Analysis of these patient age-groups from this population yielded a mean age of 33.7 years and median of 32 years.

Table 1

Number of cases classified by age

\begin{tabular}{cl}
\hline Age Group & No. of cases \\
\hline $0-9$ years & $3(1.5 \%)$ \\
$10-19$ years & $11(5.4 \%)$ \\
$20-29$ years & $59(29.2 \%)$ \\
$30-39$ years & $87(43.1 \%)$ \\
$40-49$ years & $22(10.9 \%)$ \\
$50-59$ years & $12(5.9 \%)$ \\
$60-69$ years & $5(2.5 \%)$ \\
$70-79$ years & $2(1.0 \%)$ \\
$80-89$ years & $1(0.5 \%)$ \\
\hline
\end{tabular}

Integrated analysis of data on age groups and gender of the population studied showed male patients $(n=40)$ to be evenly distributed across all age groups, whereas female cases $(n=162)$ were largely concentrated amongst the 20-29 and 30-39 years age groups (n $=124$ ).

Following analysis according to gender and identification of female cases, a further evaluation was performed identifying the type of clinical investigation patients had undergone for the laboratorial tests in question. As depicted in Table 2, there were 41 cases of prenatal investigation and 121 cases of investigation for acute disease diagnosis.

Amongst cases of acute disease investigation for both genders, we observed the occurrence of 26 cases with less than 30 percent avidity,
Table 2

Classification of female patients by age group and laboratorial test type

\begin{tabular}{lcc}
\hline & \multicolumn{2}{c}{ No. of cases } \\
Age Group & Acute disease & Pre-natal \\
\hline $10-$ 19 years & 7 & 1 \\
20 - 29 years & 33 & 19 \\
$30-$ 39 years & 55 & 17 \\
$40-49$ years & 14 & 4 \\
$50-59$ years & 10 & 0 \\
$60-69$ years & 1 & 0 \\
$70-79$ years & 0 & 0 \\
$80-89$ years & 1 & 0 \\
\hline
\end{tabular}

41 cases with intermediate avidity and 94 cases with greater than sixty percent avidity as shown in Figure 1.

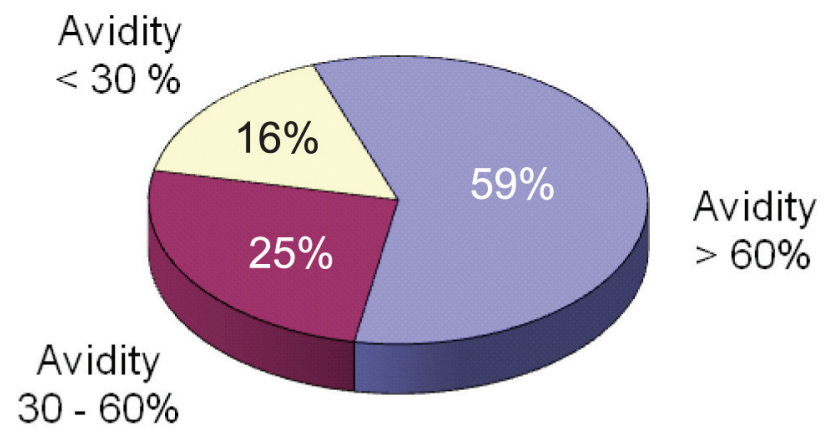

Fig. 1 - Distribution of avidity percentages among cases of acute disease investigation.

In order to verify correlation amongst IgM levels and IgG percentage avidity, IgM levels were divided into two bands: percentage avidity less than 30, and percentage avidity greater than 60, as shown in Table 3 and Figure 2 . The rationale behind using avidity percentages of less than 30 and greater than 60 was that only within this intervals can conclusive serodiagnosis of infection timing be achieved using the avidity test, corresponding to recent infection or previous infection respectively.

Table 3

Correlation between IgM levels and IgG avidity $(<30 \%$ and $>60 \%)$

\begin{tabular}{lccc}
\hline IgM range & Avidity $<30$ & Avidity $30-60$ & Avidity $>60$ \\
\hline $0.5-1.0$ & $0 \%$ & $18.7 \%$ & $81.3 \%$ \\
$1.1-2.0$ & $0 \%$ & $25 \%$ & $75 \%$ \\
$2.1-3.0$ & $16 \%$ & $28 \%$ & $56 \%$ \\
$3.1-4.0$ & $18.2 \%$ & $45.4 \%$ & $36.4 \%$ \\
$4.1-5.0$ & $44.4 \%$ & $22.3 \%$ & $33.3 \%$ \\
$5.1-6.0$ & $50 \%$ & $25 \%$ & $25 \%$ \\
$>6.1$ & $88.2 \%$ & $11.8 \%$ & $0 \%$ \\
\hline
\end{tabular}

\section{DISCUSSION}

Clinical Pathology laboratories receive samples from other labs as well as from referring physicians who deal with different kinds of 


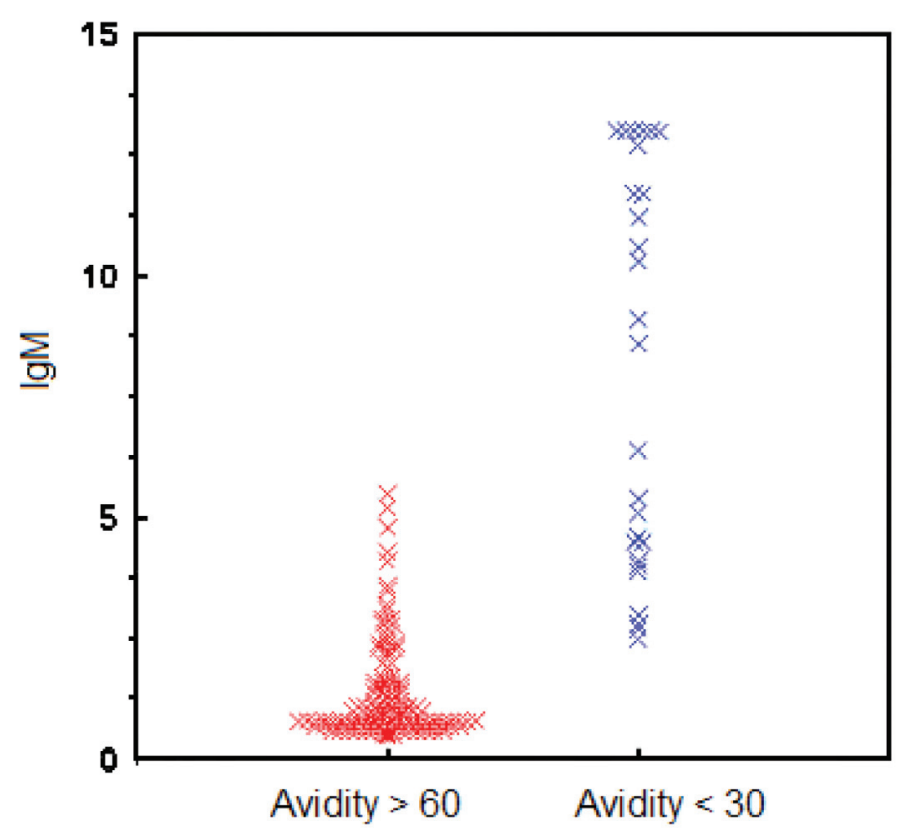

Fig. 2 - Distribution of cases of avidity ( $>60 \%$ and $<30 \%$ versus IgM levels)

situations like prenatal screening and clinical cases. Concerning toxoplasmosis, clinical suspicion arouses when a patient presents with a mono-like syndrome and the differential diagnosis has to be established with CMV, EBV infections, among others. In the context of the prenatal screening, typically no clinical suspicion exists but adequate orientations have to be given. Particularly in this situation, a reactive $\operatorname{IgM}$ to toxoplasmosis generates anxiety and might lead to interruption.

In the present study, we sought to use a broad population which was not restricted to women during the procreation period, even though this patient group represents higher risk cases and is thus more valuable for studying both the infection and disease. There are no suggestions that the behavior of the avidity results should be different during pregnancy as compared to other clinical situations.

The data on the studied population in Tables 1 and 2 show that, although the majority of individuals were female and of an age during which pregnancy is more frequent, males were also well represented, including individuals belonging to a wide range of ages and cases where laboratorial findings were used both for prenatal and acute disease investigations.

Analyses carried out on data related to gender and age group of the population revealed that male cases are distributed homogeneously across age groups, while females are more concentrated in the 20 to 39 age brackets, as depicted in Table 1. This may be attributed to the risk of occurrence of congenital toxoplasmosis in females. During pregnancy, the test allows for screening and prevention. Altered results have a different predictive value to that among individuals undergoing the test for diagnosis purposes when the predictive value of positives is greater $^{8}$.
As highlighted in Figure 3, among cases analyzed which were considered prenatal investigations, ninety percent presented an avidity greater than sixty percent, indicating that the subjects evaluated had been in contact with the parasite more than three months ago and as such presented minimal risk of transmission to the fetus. Also in this population subset, no cases of avidity of less than $30 \%$ were observed, a result congruent with the predictive value attributed to this test under these conditions of screening and prevention.

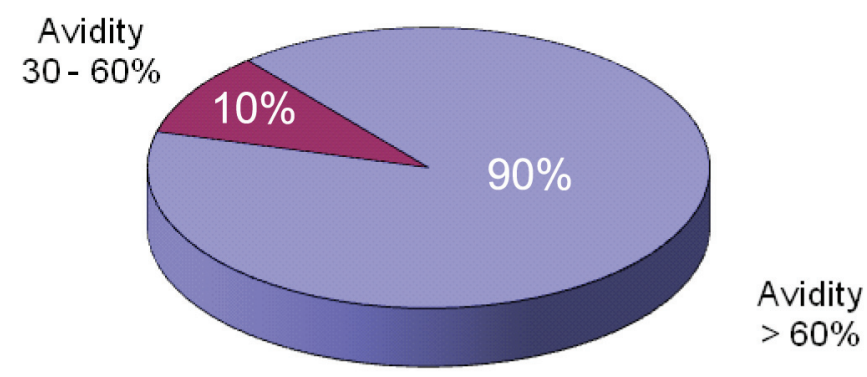

Fig. 3 - Distribution of avidity percentages among cases of prenatal investigation.

Among the population studied, eighty per cent corresponded to cases that proved to be recent disease investigations, as shown in Figure 4. Analysis of this population group reveals that fifty nine per cent of subjects had been in contact with the parasite for at least three months, while only sixteen per cent had recent contact for less than three months as depicted in Figure 1. These results clearly convey a diagnostic predictive value for this test demonstrating a positive value greater under these conditions.

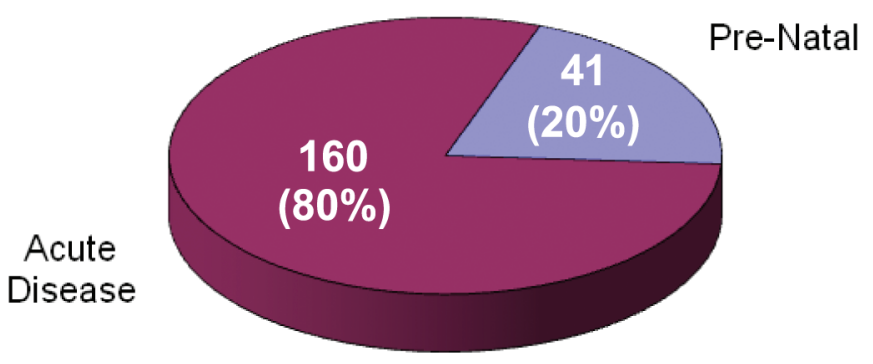

Fig. 4 - Breakdown of cases by laboratorial investigation type.

As depicted in Table 3 and Figure 2, correlation of IgM levels with $\mathrm{IgG}$ avidity percentages demonstrated that IgM levels between 0.5 and 2.0 corresponded to cases in which avidity percentages were over sixty per cent, indicating that all cases examined for this $\operatorname{IgM}$ interval constituted past or previous infection. For IgM levels ranging between 2.1 and 6.0, cases were found with avidity percentages of less than thirty percent together with cases of over sixty percent. This indicates that within this range of $\operatorname{IgM}$ values, cases studied involved both recent and previous infections. For IgM levels greater than 6.0, all cases studied presented an avidity percentage of less than thirty percent, indicating that within this range of values, all cases were of acute infection. Based on these observations, we may state that $\operatorname{IgM}$ concentrations, when resulting in values less than 2.0 or greater than 6.1 , allow satisfactory 
serodiagnostic interpretation of infection onset time, independently of the avidity test. However, $\operatorname{IgM}$ values between 2.1 and 6.0 require the performing of an avidity test to establish the timing of the infection.

Drawing on the results presented, the use of the IgG avidity test can be rationalized by performing the test only in cases where $\operatorname{IgM}$ concentrations alone prove inconclusive. It has been ascertained that such cases involve IgM levels between 2.1 and 6.0. Therefore, the avidity test can be used more rationally, essentially as an auxiliary test to aid diagnosis. In this manner, the function of the test becomes more one of clarification, allowing for clearer indication, thereby justifying its cost and the greater period required to receive results.

The results obtained in the present study allow an effective $75 \%$ reduction in performing this test. Of the 202 cases presented in this study, 153 did not present $\operatorname{IgM}$ values between 2.1 and 6.0, indicating that these cases did not require avidity values to reach serodiagnosis. A $75 \%$ reduction in performing of avidity tests can both reduce IgM test costs as well as time required for results to be made available to obstetricians and patients.

It is also very important to stress that all the values generated in this study are to be considered valid only for these particular reagents and kits mentioned here. Our previous experience comparing avidity tests results as well as IgM reactivity using kits from different manufactures allows us to say that results are not always comparable and values obtained may be different. Each laboratory must establish its own values according to the reagents and kits best fitted to their routine.

Besides, since the strategy used in this study did not include the final clinical end-point, all preview recommendations regarding discussions with the clinical/obstetric side of the medical procedure should be stimulated and therapeutic interventions used whenever clinical judgment indicates.

\section{RESUMO}

\section{Correlação entre níveis de IgM específica e percentual de avidez de anticorpos da classe IgG ao Toxoplasma gondii}

A Toxoplasmose é uma infecção universal e usualmente assintomática. A forma congênita, entretanto, pode resultar em aborto ou mal formações. Testes sorológicos estão indicados em situações onde há suspeita clínica, e na triagem pré-natal, quando são extremamente importantes para rastrear a infecção e orientar a gestante. $\mathrm{O}$ aumento da sensibilidade das técnicas para detecção de $\operatorname{IgM}$, tornou necessário o desenvolvimento de recursos, como a avidez de IgG, visando obter novo marcador de infecção aguda. Embora exista correlação entre níveis de IgM e grau de avidez de $\operatorname{IgG}$, a maioria dos testes de avidez associa-se a níveis baixos de $\operatorname{IgM}$, sugerindo que o teste de avidez não fosse necessário. Portanto, correlacionamos níveis de IgM de 202 amostras com seu respectivo nível de avidez de IgG, dirigidos contra o Toxoplasma, objetivando estabelecer valores claros para a sua indicação. Pôde-se observar que, para $\operatorname{IgM}<2,0$ e > 6,0, a definição sorológica pode ser feita independentemente da avidez. Níveis de IgM dentro desse intervalo associam-se a índices variados de avidez e, portanto, ressaltam a importância deste teste para definição sorológica do quadro. Com essa abordagem, foi possível diminuir a indicação do teste de avidez em $75 \%$, reduzir o tempo para liberação dos resultados e o custo unitário do teste para IgM.

\section{REFERENCES}

1. Amato Neto, V.; MEdeiros, E.A.S.; LEVI, G.C. \& DUARTE, M.I.S. Toxoplasmose. 4. ed. São Paulo, Sarvier, 1995.

2. BADER, T.J.; MACONES, G.A. \& ASCH, D.A. - Prenatal screening for toxoplasmosis. Obstet. and Gynec., 90: 457-464, 1997.

3. CAMARGO, M.E.; DA SILVA, S.M.; LESER, P.G. \& GRANATO, C.H. - Avidez de anticorpos específicos como marcador de infecção primária recente pelo Toxoplasma gondii. Rev. Inst. Med. trop. S. Paulo, 33: 213-218, 1991.

4. CAMARGO, M.E.; LESER, P.G. \& LESER, W.S.P. - Definição de perfis sorológicos na toxoplasmose. Importância diagnóstica e epidemiológica. Rev. bras. Pat. clín., 13: 113-127, 1977.

5. CANDOLFI, E.; PASTOR, R.; HUBER, R.; FILISETTI, D. \& VILLARD, O. - IgG avidity assay firms up the diagnosis of acute toxoplasmosis on the first serum sample in immunocompetent pregnant women. Diagn. Microbiol. infect. Dis., 58: 83-88, 2007.

6. CANTOS, G.A.; PRANDO, M.D.; SIQUEIRA, M.V. \& TEIXEIRA, R.M. Toxoplasmose: ocorrência de anticorpos anti Toxoplasma gondii e diagnóstico. Rev. Ass. méd. bras., 46: 335-341, 2000.

7. COUTINHO, S.G. \& VERGARA, T.R.C. - Toxoplasmose. In: COURA, J.R., ed. Dinâmica das doenças infecciosas e parasitárias. Rio de Janeiro, Guanabara Koogan, 2005. v. 1, p. 815-832.

8. DE PASCHALE, M.; AGRAPPI, C.; BELVISI, L. et al. - Revision of the positive predictive value of IgM anti-Toxoplasma antibodies as an index of recent infection. New Microbiol., 31: 105-111, 2008.

9. FRENKEL, J.K. \& BERMUDEZ, J.E.V. - Toxoplasmose. In: Veronesi: tratado de Infectologia. 3. ed. São Paulo, Atheneu, 2005. p. 1366-1650.

10. GUIMARÃES, A.C.S.; KAWARABAYASHI, M.; BORGES M.M.; TOLEZANO, J.E. \& ANDRADE Jr., H.F. - Regional variation in toxoplasmosis seronegativity in the São Paulo metropolitan Region. Rev. Inst. Med. trop. S. Paulo, 35: 479-483, 1993.

11. HEDMAN, K.; LAPPALAINEN, M.; SODERLUND, M. \& HEDMAN, L. - Avidity of IgG in serodiagnosis of infectious diseases. Rev. med. Microbiol., 4:123-129, 1993.

12. IQBAL, J. \& KHALID, N. - Detection of acute Toxoplasma gondii infection in early pregnancy by IgG avidity and PCR analysis. J. med. Microbiol., 56: 1495-1499, 2007.

13. JONES, J.L.; LOPEZ, A.; WILSON, M.; SCHULKIN, J. \& GIBBS, R. - Congenital Toxoplasmosis: a review. Obstet. Gynec. Survey, 56: 296-305, 2001.

14. LESER, P.G.; GRANATO, C.F.H.; SNEGE, M. et al. - A utilização do teste de avidez de IgG para auxiliar a interpretação das relações sorológicas para toxoplasmose com IgM positiva. Rev. Soc. bras. Med. fetal, 5: 16-20, 2000.

15. LEFEVRE-PETTAZZONI, M.; LE CAM, S.; WALLON, M. \& PEYRON, F. - Delayed maturation of immunoglobulin $\mathrm{G}$ avidity: implication for the diagnosis of toxoplasmosis in pregnant women. Europ. J. clin. Microbiol. infect. Dis., 25: 687693, 2006.

16. NEVES, D.P. - Parasitologia humana. 10. ed. São Paulo, Atheneu, 2003. cap. 18, p. 147-156.

17. PINON, J.M.; TOUBAS, D.; MARX, C. et al. - Detection of specific immunoglobulin E in patients with toxoplasmosis. J. clin. Microbiol., 28: 1739-1743, 1990. 
LEITE, M.; SICILIANO, S.; ROCHA, L.S.A.; JUSTA, M.T.; CÉSAR, K.R. \& GRANATO, C.F.H. - Correlation between specific IgM levels and percentage IgG-class antibody avidity to Toxoplasma gondii. Rev. Inst. Med. trop. S. Paulo, 50(4): 237-242, 2008.

18. REMINGTON, J.S.; MCLEOD, R. \& DESMONTS, G. - Toxoplasmosis. In: REMINGTON, J.S. \& KLEIN, J.O. Infectious diseases of the fetus \& newborn infant. 4. ed. Philadelphia, W.B. Saunders, 1995. p. 140-267.

19. SHARMA, S.D. - Immunology of toxoplasmosis. In: DAVID, J.W. Modern parasite biology: cellular, immunological and molecular aspects. New York, W.D. Freeman, 1990. p. $184-199$
20. STEPICK-BIEK, P.; THULLIEZ, P.; ARAÚJO, F.G. \& REMINGTON, J.S. - IgA antibodies for diagnosis of acute congenital and acquired toxoplasmosis. $\mathbf{J}$. infect. Dis., 162: 270-273, 1990

Received: 13 February 2008

Accepted: 28 May 2008 